\title{
Fight-or-Flight for America: The Affective Conditioning of Christian Nationalist Ideological Views During the Transition to Adulthood ${ }^{1,2}$
}

\author{
Michael Rotolo ${ }^{3}$
}

\begin{abstract}
Christian nationalism has gained attention both inside and outside of academia for its powerful influence on sociopolitical attitudes, voting behaviors, and political mobilization. However, limited work has examined how Christian nationalist views develop, the mechanisms by which they relate to sociopolitical attitudes, or potential varieties of Christian nationalism. Building on recent culture and cognition scholarship, this article synthesizes insights from affective neuroscience to conceptualize the fundamental role of emotions in shaping ideological views and cultural attitudes - an enculturation process termed "affective conditioning." The author then examines the development of Christian nationalist ideological views during the transition to adulthood using longitudinal interviews, field notes, and surveys with 41 Christian nationalists from the 10-year National Study of Youth and Religion (NSYR). The author identifies distinct traumatic upbringing experiences among respondents, which condition heightened RAGE and FEAR affective systems. This gives Christian nationalists an enduring sense that their way of life is "under attack" and motivates reactionary sociopolitical attitudes. The author also distinguishes two dominant affective types of Christian nationalism, dubbed "Fight for America" and "Flight for America." These findings illuminate how both past and present social conditions interact with emotional neuroarchitecture to influence ideological views and cultural attitudes.
\end{abstract}

KEYWORDS: Christian nationalism; culture and cognition; emotion; enculturation; ideology; religion.

\section{INTRODUCTION}

Recent work across the social sciences identifies the widespread presence and political salience of Christian nationalism, a unique ideology that "idealizes and advocates a fusion of Christianity and American civic life" (Whitehead and Perry 2020:11). Christian nationalism has been linked to racist, sexist, xenophobic, and Islamophobic attitudes (Braunstein 2017; Edgell 2017; McDaniel et al. 2011; Perry and Whitehead 2015), opposition to gay rights (Whitehead and Perry 2015), opposition to gun reform (Whitehead et al. 2018b), opposition to science (Baker et al. 2020a), more authoritarian attitudes on crime and deviance (Davis 2018), and voting for Donald Trump in the 2016 and 2020 presidential elections, even after controlling for political ideology, religious engagement, and other demographic vari-

1 Editor's Note: This paper is one of three winners of the Sociological Forum Graduate Student Paper competition, an event held to celebrate the 35th anniversary of the journal.

2 The author thanks Christian Smith, Terence McDonnell, the Culture Workshop at Notre Dame, Jeffrey Swindle, and the editors and anonymous reviewers for their helpful feedback on various drafts of this article. The National Study of Youth and Religion (NSYR) was funded by Lilly Endowment Inc. and the John Templeton Foundation.

3 Department of Sociology, University of Notre Dame, 4060 Jenkins Nanovic Hall, Notre Dame, Indiana 46556; e-mail: mrotolo1@nd.edu 
ables (Baker et al. 2020b; Whitehead et al. 2018a). It is also strongly associated with engaging in incautious behaviors during the thick of the COVID-19 pandemic (Perry et al. 2020).

Noting the stark contrast between the sociopolitical attitudes of Christian nationalists and the social teachings of Christianity, scholars attribute the salience of Christian nationalism to its unique beliefs and narrative. For example, Whitehead and Perry (2015:434) explain Christian nationalists' opposition to same-sex unions in terms of their "commitment to a particular narrative that (1) the United States is God's chosen country; (2) to flourish, the United States must uphold God's commands; and (3) same-sex unions are in conflict with God's commands." Whitehead et al. (2018b:10) argue, "For Christian nationalists, the gun control debate is not just about guns but about the Christian God's perceived blessing of the right to bear arms." Gorski (2017:340-341) claims that Christian nationalism draws on a "conquest narrative," "premillennial apocalypticism," and that "the metaphorical glue that binds together these two strands of discourse is a rhetoric of blood, specifically, of blood sacrifice to an angry God."

While these themes are present in Christian nationalist discourse, scholarship on culture's role in motivation has rejected the "Parsonian" view of culture, in which people are motivated by internalized beliefs and consciously desired values acquired through a process of socialization (Vaisey 2009). Such public and declarative cultural meanings are conceptualized as a "toolkit" or "repertoire" for justifying attitudes and actions, rather than motivating them (Lizardo 2017; Mills 1940; Swidler 1986; Vaisey 2009). Instead, recent scholarship on enculturation - or "the experiential ways culture comes to be internalized" (Lizardo 2021:1190)— - has shifted focus to nondeclarative culture, or culture that is implicit, habituated, and deployed quickly and automatically (Lizardo 2017; Lizardo et al. 2016; Rotolo 2021). However, these studies, too, have largely overlooked a crucial component of the enculturation process: emotion.

Building on substantive scholarship on Christian nationalism and theoretical scholarship on culture and cognition, this article synthesizes insights from affective neuroscience to conceptualize the fundamental role of emotions in shaping ideological views and cultural attitudes - an enculturation process I call "affective conditioning." I then examine how Christian nationalist ideological views develop during the transition to adulthood, drawing on longitudinal interviews, field notes, and surveys from the National Study of Youth and Religion (NSYR), a 10-year study with four waves of data. My empirical analysis focuses on 41 respondents who express Christian nationalist views in the final wave of interviews, and I use all three sources of data from all waves to trace their ideological development.

I identify distinct traumatic upbringing experiences among respondents, which condition heightened RAGE and FEAR affective systems. This gives Christian nationalists an enduring sense that their way of life is "under attack" and motivates reactionary sociopolitical attitudes. Respondents' declarative beliefs-which are generally incoherent and/or formulaic - appear to function more like a "toolkit" for justifying attitudes than a set of coherent, motivating values (Swidler 1986). I also explain how Christian nationalist ideology culminates in two dominant types based on how respondents' experiences condition their affective systems: a RAGE type, 
which I dub "Fight for America," and a FEAR type, which I call "Flight for America." These findings illuminate how both past and present social conditions interact with emotional neuroarchitecture to influence ideological views and cultural attitudes.

\section{WHAT IS CHRISTIAN NATIONALISM?}

Whitehead and Perry (2020) show that people who embrace Christian nationalism are less willing to acknowledge injustices that minoritized groups experience in America. They are less likely to believe that seeking social and economic justice is important to being a good person. And "Christian nationalism ... explained almost all of the 'religious vote' for Trump" (Whitehead and Perry 2020:62), who was already well documented for "bragging about sexually assaulting women, endorsing physical violence against his enemies, mocking the disabled, and questioning whether he has any need to apologize to God" (Whitehead et al. 2018a:165). So what is Christian nationalism, and why does it seem to paradoxically oppose both the ideals of Jesus Christ and America's constitutional democracy?

Scholars broadly define Christian nationalism as an ideology that "envision[s] the United States as Christian in its identity, values, sacred symbols, and policies" (Whitehead and Perry 2015:427). Recent quantitative studies measure adherence to Christian nationalism by examining how strongly people agree or disagree with six survey items involving the intermixing of Christian and nation-related beliefs, such as "The federal government should declare the United States a Christian nation" and "The success of the United States is part of God's plan" (e.g., Baker et al. 2020b; Davis 2018; Perry et al. 2020). Using a 24-point scale generated from these survey items, Whitehead and Perry (2020:25-26) categorize all Americans as "Ambassadors" (19.8\%), "Accommodators" (32.1\%), "Resisters" (26.6\%), or "Rejecters" $(21.5 \%)$ of Christian nationalism. Of these categories, "Ambassadors" best represent those who may also be considered "Christian nationalists" (Whitehead and Perry 2020:226).

Work on the history of religion and politics in the United States identifies powerful expressions of Christian nationalism throughout the twentieth century. Martí (2020) describes its emergence in reaction to the first Red Scare and its amplification by the Moral Majority and the Religious Right in the 1970s. Kruse (2015) links the spread of Christian nationalism to corporate and religious leaders fighting against FDR's New Deal in the 1930s and Eisenhower's responses to the Cold War in the 1950s. The addition of "under God" to the Pledge of Allegiance and "In God We Trust" to currency and stamps are only two of the many religion-related changes that took place at that time. These works and others also describe the intersections of Christian nationalism with right-wing movements, white evangelical culture, and populism in America's current political climate (e.g., Hochschild 2016; Whitehead and Perry 2020; Wuthnow 2018).

Scholarship across disciplines has particularly noted the overlap of Christian nationalism and white supremacy (e.g., Aho 1995; Barkun 1997; Butler 2021; Jones 2020; McVeigh and Estep 2020). Christian nationalism has been used to defend slavery and racial inequality (Butler 2021; Jones 2020), plays a key role in 
Ku Klux Klan ideology (McVeigh and Estep 2020), and is strongly associated with racist attitudes (Davis and Perry 2021; Perry and Whitehead 2015; Perry et al. 2019). Studies of white supremacists and Christian nationalists also describe similar negative emotions among respondents (e.g., Simi et al. 2019; Whitehead and Perry 2020).

Finally, prior work explains the motivating power of Christian nationalism in terms of its unique beliefs and narrative. Central is "the belief that (1) God chose the United States and (2) the United States must follow God's commands to flourish" (Whitehead and Perry 2015:423). Gorski (2017) links Christian nationalism to parallels between America and Old Testament Israel and the need to preserve a distinct people and culture. The Christian nationalist narrative differs from that of "civil religion," which focuses on "America's covenantal relationship with a divine Creator who promises blessings for the nation for fulfilling its responsibility to defend liberty and justice" (Whitehead et al. 2018a:150). While civil religion focuses on beneficence and stewardship to maintain its covenant with God, Christian nationalism "demands more in terms of allegiance to our national-almost ethnic - Christian identity" and focuses on God's wrath for disobedience (Whitehead and Perry 2020:11). These descriptions highlight the public and declarative elements of Christian nationalism to explain adherents' sociopolitical attitudes.

\section{THE AFFECTIVE ROOTS OF IDEOLOGIES AND CULTURAL ATTITUDES}

While the public and declarative elements of Christian nationalism provide certain moral justifications for adherents' attitudes, cognitive scientists have shown that moral judgment and decision making are not driven primarily by internalized beliefs and moral reasoning, as the rationalist tradition and Parsonian view of culture supposed (e.g., Greene et al. 2001; Haidt 2001). Haidt (2006) - whose explication of "dual-process models" heavily influenced the growth of cognitive cultural approaches in sociology via Vaisey (2009) - metaphorically likens human cognition to "a rider on the back of an elephant." Vaisey (2009:1683) summarizes,

\footnotetext{
The rider, who represents our conscious processes ... can talk, reason, and explain things to our heart's content. Yet, for the most part, she is not in charge. The elephant, which stands for our automatic processes, is larger and stronger than the rider and is totally unencumbered by the need, or the ability, to justify itself.
}

This is not to say that declarative beliefs and values play no role in motivation, but rather that "in any given moment, the elephant ... is usually in charge" (Vaisey 2009:1683). ${ }^{4}$

These insights have led many sociologists interested in motivation and enculturation to shift focus to nondeclarative culture, or culture that is implicit, habituated, and deployed quickly and automatically (Lizardo 2017; Lizardo et al. 2016). Much of this work focuses on tacit cognitive structures or "schemas" (e.g., Boutyline and Soter 2021; Hunzaker and Valentino 2019; Leschziner and Brett 2021; Rotolo 2020;

\footnotetext{
${ }^{4}$ Scholars have also critiqued dual-process models as too simplistic and dualistic (e.g., Leschziner and Green 2013; Winchester 2016). However, the basic insight that fast, automatic, and intuitive cognitions play a central role in motivation remains dominant.
} 
Wood et al. 2018). As a result, sociologists have developed better explanations of how people think, judge, and act prior to conscious evaluation.

However, as Abrutyn and Lizardo (2020:88) argue, "the introduction of neuroscience to sociology has relegated affect and emotion to the background, focusing on more cognitive processes." Cognitive cultural approaches have tended to focus on "abstract information processing" without considering the thoroughly embodied nature of cognition (Ignatow 2021). In a recent Annual Review of Sociology piece focused on forward paths for the study of culture and cognition, Cerulo et al. (2021:73) suggest, "more empirical work can examine the interactional dynamics that give rise to shared and collective emotions." This article seeks to chart out in greater depth the fundamental role of emotion, particularly affect, in the enculturation process.

Sociology, of course, has a robust "sociology of emotions" (e.g., Collins 2005; Hochschild 1983; Turner and Stets 2006). Many sociological studies identify the emotions of politics and political mobilization (e.g., Goodwin et al. 2001; Jasper 2018; Summers-Effler 2010). However, advances in neuroscience offer sociologists constructive ways to understand the most fundamental motivational properties and goals of different emotions (Abrutyn and Lizardo 2020). In particular, insights from affective neuroscience trace emotions to specific neural regions and electrochemical pathways and explain how they influence adaptive behaviors in all mammals prior to conscious awareness (Davis and Montag 2019; Panksepp 1998).

Jaak Panksepp, who pioneered affective neuroscience in the 1990s, identifies seven "foundational affective systems" with distinct neural pathways that constitute humans' basic motivational drives: SEEKING, FEAR, RAGE, PANIC, LUST, CARE, and PLAY. Panksepp (1998:52) found that electrically or chemically stimulating a system's particular neuroanatomical location evokes "essentially identical emotional tendencies" and "emotional behaviors" in mammals. Of these seven systems, SEEKING, FEAR, and RAGE are considered primary affective systems, whereas PANIC, LUST, CARE, and PLAY are considered secondary affective systems, partially dependent on learned associations through social interaction (Asma and Gabriel 2019; Panksepp 1998). These subcortical systems comprise our "primary form of sentience" and "intentional core," evolved to aid survival and maintain homeostasis, similar to the way the body regulates hunger, thirst, and temperature (Asma and Gabriel 2019:27).

While all of these affective systems play important roles in motivation, I argue that the three primary affective systems are especially pertinent for understanding ideologies and cultural attitudes. Much of what is considered openminded, accepting, and prosocial versus uncompromising, disciplined, and dutiful relates to the arousal and regulation of the SEEKING system versus the RAGE and FEAR systems. PANIC primarily relates to separation anxiety or grief, LUST relates to sexual urges, CARE relates to nurturing offspring, and PLAY relates to joy from social play (Panksepp 1998). Thus, I briefly describe the three primary systems.

The SEEKING system motivates organisms to explore, evolving from humans' needs to seek out food, water, warmth, relationships, and other resources. Its main neurotransmitter is dopamine, and its arousal is characterized by heightened desire, attention, and curiosity (Panksepp 1998). Stimulants can create a similar form of arousal, and Panksepp (1998:145) says the activation of the SEEKING system is 
"akin to that invigorated feeling of anticipation we experience when we actively seek thrills and other rewards." Its activation is associated with prosocial behaviors and ideological openness (Narvaez 2014; Panksepp 1998).

The RAGE system motivates the body to defend its territory and possessions by arousing a "fight" response (Panksepp 1998). It is most commonly evoked by restricted freedom, limited resources, and suppression of the SEEKING system. It is characterized by anger, aggression, and resentment, and it "persuades us that the offending agent is below contempt and deserves harm" (Panksepp 1998:191). In primates, this system's intensity "amplifies exponentially when agents perceive that they are not satisfying their desires while others are" (Asma and Gabriel 2019:256).

The FEAR system helps organisms avoid danger and arouses a "flight" response (Panksepp 1998:54). It is characterized by anxiety and tension, which alarm an organism that their safety is threatened. Parts of the FEAR system overlap with the RAGE system, and Panksepp (1998:208) notes, "It makes good evolutionary sense for FEAR and RAGE circuits to be intimately related, for one of the functions of anger is to provoke fear in competitors, and one of the functions of fear is to reduce the impact of angry behaviors from threatening opponents."

Above these three primary affective systems and the four secondary affective systems, we may think of a tertiary level of emotions, which involves subjective evaluation in the neocortex. This is the layer of emotions that sociologists typically focus on, including feelings such as pride, shame, guilt, jealousy, and embarrassment (Kemper 1987; Plutchik 1980; Turner and Stets 2006). Many scholars seeking to explain Christian nationalism and related ideologies have described these tertiary sentiments, even referencing "anger and mourning" (Hochschild 2016) and "rage" (Wuthnow 2018) in their titles. For example, Hochschild (2016:135) describes anger, fear, mourning, and resentment among Trump supporters as part of a "deep story" or "feels-as-if story" that "tells us how things feel."

However, the primary affective systems play a more fundamental role in the automatic appraisals that shape ideological views and attitudes. Studying them can help systematically identify causes, adaptational motivations, and expected behavior patterns for different emotions.

\section{AFFECTIVE CONDITIONING AS A PROCESS OF ENCULTURATION}

Drawing on these insights, I conceptualize affective conditioning as an enculturation process, in which affective systems adapt to environmental cues in the attempt to maintain homeostatic balance. Humans' unique social experiences condition which affective systems are aroused, their intensity, and their targets. Those affective systems then automatically appraise incoming stimuli before we can consciously recognize, evaluate, or reason about them (Cozolino 2006; Damasio 1994; Panksepp 1998). The constant interaction of these affective systems with specific social environments generates different affective lenses such that people with different emotional histories "will literally see the world somewhat differently" (Turner 2007:116).

When humans express their ideological views and attitudes, the narratives they espouse largely serve as "a strategy for neural integration" and "foster emotional 
security while minimizing the need for elaborate psychological defenses" (Cozolino 2006:304). While various ideological commitments may involve moral reasoning, there is a "priming effect' of existing emotional arousal ... that, in turn, affects which moral codes are involved and how they are interpreted" (Turner 2007:116). Humans can usually come up with many different lines of moral reasoning based on which affective systems are aroused. Thus, better understanding humans' ideological views and attitudes requires understanding how they are affectively conditioned.

Humans appear to enter the world with some innate capacities for altruism and cooperation (Bloom 2013). However, humans' primary affective systems mature after birth, and affective conditioning is heavily shaped by childhood experiences. Numerous studies show that a warm, nurturing, and attentive relationship between caregiver and child supports optimal development of emotion systems. Positive experiences conveying safety and trust can enhance humans' SEEKING system and encourage curiosity, ideological openness, and the desire to engage in prosocial actions (Asma and Gabriel 2019; Narvaez 2014; Tomkins 1965).

On the other hand, traumatic and non-responsive early-life experiences can lead to poor emotional regulation (Asma and Gabriel 2019; Narvaez 2014; Panksepp 1998; Tomkins 1965). Negative experiences that cause shame, fear, anger, or embarrassment can lead to greater reactivity of the RAGE and FEAR systems and a reliance on defense mechanisms later in life. Those with these experiences are more likely to develop a self-protective disposition, which can produce "black-andwhite" habitual prejudgments, rigid adherence to routines, stereotyping, territoriality, egocentric decision making, and reliance on slogans and maxims representing ingroup loyalty, hierarchy, and submission to authority (Jost et al. 2003; Narvaez 2014), as in the findings of this study.

A large social scientific literature going back to Freud focuses particularly on these negative consequences of trauma. For example, research in criminology has identified some of the ways traumatic childhood experiences enculture white supremacist views and lead to violent extremism later in life (e.g., Simi et al. 2016). The word "trauma" originates from ancient Greek, meaning "wound" or "damage" (Leys 2000). Freud's (1961:19-20) association of trauma with the "compulsion to repeat ... repressed material as a contemporary experience" is suggestive of how people become encultured by damaging emotional experiences. Connecting this work to research on affective systems can further clarify the specific mechanisms by which traumatic experiences shape ideology and attitudes.

Additionally, while many studies emphasize early-life experiences, affective systems continue to adapt beyond childhood. The adolescent brain shows disorganization and reorganization of neural networks into the early 20s (Cozolino 2006; Nelson et al. 2005). After this age, affective systems tend to be more stable. However, some level of plasticity remains as humans continue to encounter new circumstances to which they need to adapt. This may help explain Kiley and Vaisey's (2020) findings of little persistent attitudinal change across 183 items from the 2006 to 2014 rotating panels of the General Social Survey. Affective conditioning illuminates why attitudes tend to have a "settled dispositional" quality among adults, while still "susceptible to updating shocks," especially among young people 
(Kiley and Vaisey 2020:496). Kiley and Vaisey (2020:500) conclude, "Panel studies tracing the political socialization of adolescents are rare but could be highly fruitful" to "understand how these attitudes are formed."

Focusing on the conditioning of humans' affective systems enables better understanding of the process of enculturation, the fundamental motivational goals of particular attitudes and actions, and the mechanisms of stability and change in cultural attitudes. The current study examines these dynamics among Christian nationalists during the transition to adulthood.

\section{DATA AND METHODS}

My data come from the 2002-2012 National Study of Youth and Religion. ${ }^{5}$ The NSYR consists of four waves of nationally representative telephone surveys and in-person, in-depth interviews with young Americans from around the country and focuses on their backgrounds, family relationships, religious views, sociopolitical views, and aspirations. Wave 1 was conducted in 2002-2003 when respondents were ages 13-17. Wave 2 was conducted in 2005 when respondents were ages 16-20. Wave 3 was conducted in 2007-2008 when respondents were 18-23. Wave 4 was conducted in 2012 when respondents were $23-28$.

I began by identifying those who expressed Christian nationalist views in the Wave 4 interviews, as the surveys did not ask questions specifically indicating adherence to Christian nationalism. I examined the entirety of the 292 interviews for Christian nationalist views. However, these views were most often expressed in a section focused on the role of religion in society and questions, such as "Would anything be lost or gained if the U.S. became much more religious" and "Should religion have a role in public debates?" 41 of the 292 interviewees in Wave 4, or 14\%, expressed Christian nationalist views involving the blending of Christian and nationrelated beliefs. Table I provides example excerpts of respondents' views.

I also considered respondents' answers to relevant Wave 4 survey questions. Of those coded as Christian nationalists, $100 \%$ identified as Christian on the survey, compared to $44 \%$ of other respondents. One hundred percent of Christian nationalists also agreed "Right and wrong should be based on God's law," compared to 33\% of other respondents. Table II shows the descriptive statistics of the sample. The two non-white respondents who expressed Christian nationalist views self-identified as Latino and Egyptian-American. Their views were similar to others'. However, Christians of different races often have different attitudes on political issues, such as the causes of racial inequality (e.g., Edgell and Tranby 2007; Perry and Whitehead 2019). Thus, the attitudes of Christian nationalists from minoritized racial groups may differ from my findings.

To examine the development of Christian nationalist views, I used all available interviews, field notes, and surveys for the 41 identified Christian nationalists. In total, I coded 118 in-depth interviews. Table III shows the waves of interview data available for respondents. Though I focused on the mechanisms leading to Christian

\footnotetext{
5 For more information on research design, see Smith and Denton (2005).
} 
Table I. Example Interview Excerpts Denoting Christian Nationalist Ideology

\begin{tabular}{|c|c|c|c|c|}
\hline Age & Gender & Race & Religious tradition & Excerpt \\
\hline 26 & Female & White & $\begin{array}{l}\text { Evangelical } \\
\text { Protestant }\end{array}$ & $\begin{array}{l}\text { "This country was founded on faith and on God. The } \\
\text { men that did the Declaration: they were Christians, } \\
\text { they loved God, they followed him, they had great } \\
\text { morals." }\end{array}$ \\
\hline 26 & Male & White & $\begin{array}{l}\text { Christian } \\
\text { Non-attender }\end{array}$ & $\begin{array}{l}\text { "I'm very much against the whole, you know, 'Let us } \\
\text { take God off our money, let us take God out of the } \\
\text { Pledge of Allegiance.' That's not right ... I think the } \\
\text { foundation of the whole country ... we are built } \\
\text { around, you know, trusting God, and I do think that's } \\
\text { why our country's probably better off than most." }\end{array}$ \\
\hline 24 & Female & White & Latter-day Saint & $\begin{array}{l}\text { "I mean our country was founded on the premise that } \\
\text { we, you know, 'In God We Trust,' and I think that's } \\
\text { not something we should lose ... I think that we need } \\
\text { to hold true to those original values." }\end{array}$ \\
\hline 24 & Male & White & $\begin{array}{l}\text { Evangelical } \\
\text { Protestant }\end{array}$ & $\begin{array}{l}\text { "I think religion should play a role just because you have } \\
\text { a lot of people claiming to be Christians, and this } \\
\text { country is founded on, you know, Christian beliefs." }\end{array}$ \\
\hline 28 & Female & White & $\begin{array}{l}\text { Christian } \\
\text { Non-attender }\end{array}$ & $\begin{array}{l}\text { "I do not think that [Christianity] should be tooken out } \\
\text { of society, like schools and stuff like that ... Like the } \\
\text { Pledge of Allegiance... If you do not wanna say } \\
\text { ['under God'], do not say it. But I do not think it } \\
\text { should be tooken out." }\end{array}$ \\
\hline 27 & Male & White & $\begin{array}{l}\text { Evangelical } \\
\text { Protestant }\end{array}$ & $\begin{array}{l}\text { "If you look at any other country who has, for lack of a } \\
\text { better word, 'forsaken' God, immediately they made a } \\
\text { turn for the worst. And that's exactly what ours is } \\
\text { doing. 'Forget me, I'll forget you.' It's that type of } \\
\text { thing." }\end{array}$ \\
\hline 24 & Female & White & $\begin{array}{l}\text { Evangelical } \\
\text { Protestant }\end{array}$ & $\begin{array}{l}\text { "I would hope that if the country was more widespread } \\
\text { Christian that the level of morality would hopefully go } \\
\text { up ... we are based on Christian founders. Um, but } \\
\text { knowing the way the country is now, people would } \\
\text { freak out "cause they are trying to throw God out of it } \\
\text { no matter what we were founded on." }\end{array}$ \\
\hline 26 & Male & White & Latter-day Saint & $\begin{array}{l}\text { "We believe certain things with regards to marriage and } \\
\text { family and, and um, just things like that ... It sort of } \\
\text { blurs the lines a little bit with regards to, you know, } \\
\text { church and politics or whatever. But I mean that's } \\
\text { what I believe, and so there's not much I can do to } \\
\text { change it." }\end{array}$ \\
\hline
\end{tabular}

nationalist views, I also examined the interviews and surveys of other respondents to get a sense of how their experiences compared.

I coded the interviews abductively, which involves iterative movement between data and theory (Danermark et al. 2002; Peirce 1998:1901; Timmermans and Tavory 2012). I started by reading through the interviews and writing memos of themes, which I considered in light of other studies of Christian nationalism. I then systematically coded recurring themes, as well as visceral information, such as tone, expressions, gestures, pauses, confusion, and discomfort (Pugh 2013; SummersEffler et al. 2015). Listening to audio recordings of the interviews helped me identify this type of information. I also used transcriber notes and field notes provided by the interviewers. This was a rich source of data. Interviewers were unaware of this project and the respondents I focus on, yet their field notes describe the emotional 
Table II. Descriptive Statistics of Christian Nationalist Respondents Compared with Non-Christian Nationalist Respondents

\begin{tabular}{|c|c|c|}
\hline & $\begin{array}{c}\text { Christian nationalists } \\
N=41 \\
\% \text { of sample }\end{array}$ & $\begin{array}{c}\text { Non-Christian nationalists } \\
N=251 \\
\% \text { of sample }\end{array}$ \\
\hline Female & 51 & 51 \\
\hline \multicolumn{3}{|l|}{ Race } \\
\hline Black & 0 & 14 \\
\hline Latino & 3 & 12 \\
\hline Other & 3 & 10 \\
\hline White & 93 & 65 \\
\hline \multicolumn{3}{|l|}{ Region } \\
\hline Midwest & 22 & 23 \\
\hline Northeast & 2 & 20 \\
\hline South & 42 & 33 \\
\hline West & 34 & 24 \\
\hline \multicolumn{3}{|l|}{ Highest education level } \\
\hline No degrees & 5 & 4 \\
\hline High school or GED & 41 & 40 \\
\hline AA/Voc. Tech & 12 & 9 \\
\hline BA & 37 & 41 \\
\hline Graduate degree & 5 & 6 \\
\hline \multicolumn{3}{|l|}{ Religious tradition } \\
\hline Black protestant & 0 & 7 \\
\hline Catholic & 10 & 11 \\
\hline Evangelical protestant & 49 & 11 \\
\hline Jewish & 0 & 8 \\
\hline Latter-day saint & 22 & 2 \\
\hline Mainline protestant & 0 & 6 \\
\hline Not religious & 0 & 44 \\
\hline Other & 0 & 3 \\
\hline "Just Christian" attender & 10 & 2 \\
\hline Christian non-attender & 10 & 6 \\
\hline \multicolumn{3}{|l|}{ Political affiliation } \\
\hline Democrat & 5 & 34 \\
\hline Independent & 27 & 39 \\
\hline Republican & 59 & 12 \\
\hline Other/Do not know & 10 & 17 \\
\hline
\end{tabular}

states of respondents in depth and identify distinct and consistent themes, which I discuss below. All names are pseudonyms.

To be clear, I did not directly observe the activity of respondents' affective systems. As Panksepp (1998:9) explains, "Such states remain difficult-some claim impossible - to study empirically ... the study of emotional states must be indirect and based on empirically guided theoretical inferences." This is the case for many of the concepts and phenomena social scientists wish to study. Instead, by becoming familiar with the causes, motivational goals, and indicators of each affective system's activation as established by prior studies, clear sequential patterns in respondents' experiences, emotions, attitudes, and explanations became apparent. Attending to these affective systems illuminates the development of Christian nationalist views, the mechanisms underpinning respondents' attitudes, and varying forms of Christian nationalism. 
Table III. Waves of Interview Data for 41 Christian Nationalist Respondents

\begin{tabular}{lcc}
\hline Waves completed & Frequency of respondents & \% of respondents \\
\hline $1,2,3,4$ & 14 & 34.15 \\
$1,2,4$ & 1 & 2.44 \\
$1,3,4$ & 12 & 29.27 \\
1,4 & 2 & 4.88 \\
3,4 & 7 & 17.07 \\
4 & 5 & 12.20 \\
\hline
\end{tabular}

\section{THE AFFECTIVE CONDITIONING OF CHRISTIAN NATIONALIST VIEWS}

In analyzing the experiences and developing views of Christian nationalists over 10 years, a distinct pattern emerged: (1) Christian nationalist respondents conveyed traumatic upbringing experiences involving physical punishment, intense verbal disciplining, shaming, extreme supervision and sheltering, and various manipulative and controlling behaviors by their parents and surrounding elders, (2) this trauma caused psychological distress and conditioned heightened negative affective systems, giving them an enduring sense that their way of life is "threatened" and "under attack," and (3) this motivated reactionary sociopolitical attitudes, which involve a rejection of progressive changes and a desire to return to the past or "good ol' days."

Consistent with what Vaisey (2009) observed while studying youth in the NSYR, respondents expressed inconsistent and incoherent moral beliefs and ideals. Christian nationalists often rationalized their views using fragmented pieces of Christianity, American heritage, or laws, but they did so with great difficulty and contradiction. Christian nationalist rhetoric functioned more like a "toolkit" for justifying their attitudes than a set of coherent, motivating beliefs and values (Swidler 1986). It served as a way for respondents to claim that their views were from God and foundational to America. "America's Christian values"-which represented the moral views of their particular subculture - thus became the specific target under attack.

When asked whether the United States is heading in a good direction, a 25year-old white evangelical woman claimed, "It's very hard for Christians to openly walk what they believe. And people don't want to admit it ... but Christians are one of the more oppressed social groups in America today!" A 27 year-old white Latterday Saint man expressed,

I'd almost call it like intolerance of religion. You know, people getting up in arms about phrases like, "In God We Trust." I don't know why they would ... [nervous laughs] ... go after something our forefathers established because of their personal agendas. Um, and I-I-I worry that our society's getting too focused on, um, rights of the minority, and they're starting to overlook the rights of the majority!

A 26-year-old white evangelical man said, "It's getting less and less okay to act on believing in God. The fact that they're trying to take out 'One nation under God' ... a lot of times you can't pray in schools anymore!" A 20 -year-old white evangelical man lamented "the strong push for pushing religion out of everything ... only teach evolution in school, and more defending the rights of homosexuals as to the exclusion of being able to talk about them in a negative way!" 
These responses were significantly different from those of respondents who were not Christian nationalists. Other respondents expressed that the United States, though imperfect, was at least moving in the right direction. A 28 -year-old Latina Catholic woman said, "As a society, I feel like people are very supportive, helpful, crime rates are low. I guess where I'm at, it's good." A 26-year-old white Mainline Protestant woman claimed, "I'm confident ... I think it's only gonna get better ... like it can't get worse." These other respondents also recognized immorality as a problem in society. However, few perceived immorality as a matter of forsaking the standards and values of America's past. Rather the moral concerns they articulated were as follows: challenges to accessing education, unnecessary wars, school shootings and gun violence, materialist consumerist capitalist culture, diplomacy in the nuclear age, prison reform, racism, global warming, income inequality and the wealth gap, and the political power of corporations.

While the general pattern of trauma, negative affective dispositions, and reactionary sociopolitical views was consistent across all Christian nationalists, there was also significant variation among respondents. I identify two dominant types of Christian nationalism associated with unique experiences of affective conditioning. One is more strongly rooted in the RAGE affective system, which I dub "Fight for America," and the other in the FEAR affective system, which I call "Flight for America." Though respondents tended to exhibit one type more than the other, they sometimes displayed elements of both types. Panksepp (1998) shows that the RAGE and FEAR systems are overlapping both structurally and in terms of their evolved goals. Signs of the SEEKING system were absent. Table IV summarizes the primary differences in the two types. The percentages in the bottom half of the table are derived from survey responses.

\section{"Fight for America"}

About one-quarter of Christian nationalists conveyed experiences and emotions indicating that their RAGE system played a dominant role in their appraisals. This Christian nationalist type is characterized by frustration, aggression, and jabs toward "them," the perceived "other side." Tribalism was common among these respondents, which sometimes manifested as nativism and racism. Consistent with explanations of the RAGE system's goals (and not mere anger sentiments), respondents' views centrally concerned protecting themselves, their freedoms, and their resources, as well as a perception that others were receiving unfair preferential treatment.

Though respondents described experiences throughout their lives that conditioned an inner RAGE, their emotions were strongly shaped by their upbringings in environments of scarcity, family dysfunction, hostility, and "tough love" bullying tactics. In most cases, respondents' fathers were the source of emotional trauma. A 14-year-old boy explained, "With my dad ... I think it's more of a hysterical relationship. We get along pretty good, but like if my dad's mad, you better get out of his way "cause he has almost like a rage problem." An 18-year-old man shared, "When I moved out, I actually broke my dad. I had always had a speech in mind ... So right when I was moving out, I gave him the speech: 'F-you, I hate you, I don't 
Table IV. Two Dominant Affective Types of Christian Nationalist Views

\begin{tabular}{|c|c|c|}
\hline Affective system & $\begin{array}{l}\text { "Fight for America" } N=11 \\
\text { RAGE }\end{array}$ & $\begin{array}{c}\text { "Flight for America" } N=30 \\
\text { FEAR }\end{array}$ \\
\hline Affective Disposition & $\begin{array}{l}\text { Frustrated, combative, } \\
\text { externalizing, aggressive, } \\
\text { active, dominant }\end{array}$ & $\begin{array}{l}\text { Anxious, compliant, internalizing, } \\
\text { withdrawing, passive, submissive }\end{array}$ \\
\hline $\begin{array}{l}\text { Experiences Conditioning } \\
\text { Affects }\end{array}$ & $\begin{array}{l}\text { Hostile parents, dysfunctional } \\
\text { family relationships, being } \\
\text { bullied, economic hardship }\end{array}$ & $\begin{array}{l}\text { Controlling parents, homogeneous } \\
\text { and insulated subcultures, fear } \\
\text { and guilt-based religious } \\
\text { upbringings }\end{array}$ \\
\hline $\begin{array}{l}\text { Strategies for Explaining } \\
\text { Attitudes }\end{array}$ & $\begin{array}{l}\text { Shallow slogans, adages, } \\
\text { conspiracies; ad hominem } \\
\text { attacks on others }\end{array}$ & $\begin{array}{l}\text { Dogmatic and memorized } \\
\text { doctrinal claims, formulaic } \\
\text { beliefs; writing off other views as } \\
\text { hoaxes }\end{array}$ \\
\hline Relation to Organized Religion & $\begin{array}{l}\text { Emphasizes personal belief over } \\
\text { church involvement; may see } \\
\text { churches as judgmental }\end{array}$ & $\begin{array}{l}\text { Heavily involved in church; church } \\
\text { is main form of community and } \\
\text { social engagement outside of } \\
\text { their families }\end{array}$ \\
\hline Personal Morality & $\begin{array}{l}\text { Knows "the basics" of the Bible } \\
\text { and "the law," but can justify } \\
\text { whatever actions they take; } \\
\text { often break many rules }\end{array}$ & $\begin{array}{l}\text { Strict moral code; generally against } \\
\text { premarital sex, cohabitation, } \\
\text { divorce, drugs, smoking, and } \\
\text { breaking the law; alcohol } \\
\text { sometimes okay in moderation }\end{array}$ \\
\hline $\begin{array}{l}\text { View of Humanity and Life in } \\
\text { the World }\end{array}$ & $\begin{array}{l}\text { It's a dog-eat-dog world, you } \\
\text { get what you deserve, and } \\
\text { your feelings are irrelevant; } \\
\text { rules keep society under } \\
\text { control }\end{array}$ & $\begin{array}{l}\text { We are all sinners deserving of } \\
\text { wrath who constantly face } \\
\text { temptation; we need discipline, } \\
\text { boundaries, and guidelines to } \\
\text { avoid evil }\end{array}$ \\
\hline Female & $36 \%$ & $57 \%$ \\
\hline School Type & $\begin{array}{l}82 \% \text { public, } 9 \% \text { private, } 9 \% \\
\text { dropped out }\end{array}$ & $\begin{array}{c}57 \% \text { public, } 23 \% \text { religious private, } \\
17 \% \text { homeschool, } 3 \% \text { private }\end{array}$ \\
\hline $\begin{array}{l}\text { Parent Said They Had a Bad } \\
\text { Temper }\end{array}$ & $73 \%$ & $27 \%$ \\
\hline $\begin{array}{l}\text { Said Experienced Trauma as a } \\
\text { Teen }\end{array}$ & $82 \%$ & $44 \%$ \\
\hline Earned BA Degree & $9 \%$ & $50 \%$ \\
\hline $\begin{array}{l}\text { Less than } \$ 5 \mathrm{k} \text { Total Wealth/ } \\
\text { Assets }\end{array}$ & $64 \%$ & $10 \%$ \\
\hline $\begin{array}{l}\text { Attend Church Weekly or } \\
\text { More }\end{array}$ & $9 \%$ & $83 \%$ \\
\hline Has Smoked Cigarettes & $73 \%$ & $0 \%$ \\
\hline Has Drank Alcohol & $91 \%$ & $50 \%$ \\
\hline Says Divorce Okay & $91 \%$ & $17 \%$ \\
\hline $\begin{array}{l}\text { Says Abstain from Sex Until } \\
\text { Marriage }\end{array}$ & $9 \%$ & $87 \%$ \\
\hline
\end{tabular}

care!' And he broke down, just in tears." A 24-year-old man shared, "When I was growing up, some people would say we had the short end of the stick. Like, my dad was an asshole. He chose drugs, cars, and whores over us. There was times when all we had to eat was water, ketchup, and crackers, and he would go get a cheeseburger plate and come back, eat it in front of us."

Interviewer field notes similarly described respondents as "very aggressive and animated" and "cocky and pushy" with "lots of posturing." They noted emotional numbness. One interviewer wrote, "Shows very little emotion but would express anger or humor occasionally ... would sometimes lock into an emotionless cold stare." 
Interviewers also observed respondents' clear struggles to answer questions about morality. One interviewer said, "Most of his beliefs and perspectives seemed to have been fed to him by adult figures. He doesn't seem to have thought much about these types of questions. The most important theme for him is being a 'winner,' which [he says] means "competitively conquering." Some respondents were also aware of their RAGE. A 19-year-old man shared, "I have an aggressive temper. If I get pushed to the limit ... I've gotten so mad before that I've blacked out and don't remember what I'm doin'."

One of the most polite interviewees in the entire sample was Ben, a 15-year-old, working-class Pentecostal boy from Mississippi. Ben's parents divorced when he was 5 , which he claimed "kind of affected me ... at first, you think it was you or something." When talking about his stepfather, he says, "His feathers get ruffled kind of easily ... If he says something, most the time you're going to say, 'Yes sir!' I mean arguing is just going to get him even madder and is going to get me in worser trouble "cause I'm arguing with my elder."

Ben was confused when asked about morality, not understanding how morality may not be obvious, clear-cut, and understood by everyone. He finally responded,

I think kind of the basic rule of life should I say is: life doesn't really care ... I'm not prejudice, but I'm going to use this example of ... black people. If something doesn't quite go the way that they really want it to or something, somehow one way or another they'll say that the influence of prejudice had something to do with it, and they'll kind of use that as a crutch in order to get what they wanted.

Articulating this emotionally tense view seemingly triggered Ben's RAGE, leading him to share other ways he feels under attack. Without any prompting, he next described hearing on the radio that a school district did not allow red and green pencils around Christmas, punished students for wearing clothes with Santa Claus on them, and forced them to read the Koran. He exclaimed boldly, "I'm going to wear whatever I want to wear! If it has Santa Claus on the back of it, I'm just expressing my own religious belief!"

When asked about religion, Ben recited memorized metaphorical imagery that he struggled to recall: "We would all never barely even be able to uh ... stand up to shall we say even the dust particle ... that the dust particle by God's feet, we are still not without all that $\mathrm{He}$ is" and "We cannot look upon Him "cause if we did, we would immediately go blind ... He's so, as pure, as holy as He is, like I said it says in the Bible, we cannot even look on Him or we'll go blind."

In Wave 2, Ben explained that he "grew a distaste of [his] actual birth father" and had "a few odds with [my stepdad] too." He continued, "You don't cross him ... and if you do end up crossing him, you better watch out!" Little else changed for Ben, and he still spent his time surrounded almost solely by his parents and a few friends who he claimed share the same values. When asked about what makes something right and wrong, Ben says, "Being here in America ... I guess it'd be somewhat safe to say the whole general atmosphere is about the same, which is Christian-based."

By Wave 3, Ben dropped out of high school, got his GED, joined the military, and started participating in Civil War reenactments. He shares, "Part of my childhood was always being the one that was one of those ones that was the bully magnet." RAGE-based political sentiments were a prominent part of the interview. He described hatred for Obama and "the lunacy and the sheer fact of no morals," 
referencing shootings, crack houses, gangsters, ghetto projects, and "freeloading off our tax dollars and systems." He added, "Someone could probably easily call me racist and prejudice, but I'll call things as they seem. If the boot fits, that person oughta wear it! Very rarely will you hear me call someone a nigger. But quite frankly, there is differences between a nigger and a black man!" As for his religious views, Ben no longer attends church and focuses on personal belief, which he erroneously explains, "Is it Martin Luther? I wanted to say, 'Martin,' but I was like, 'That's not right.' When Martin Luther put up fifty-five things of reclamation ... if you look at what the Bible tells you, it says, 'By faith alone you will be saved."'

Finally, in Wave 4, Ben lives at home with his parents, is a maintenance worker, and regrettably feels like he has not found his purpose. He remains friends with two guys from childhood and claims, "We were kinda the weird outcasts ... the ones nobody really wanted to be around." When asked about his moral views, he says, "Here in the Christian world, we go off the ethics that are taught in the Bible." Ben rarely goes to church but explains, "When you look in the Bible, here's the black and white. That's what I think of God. He's the part of your father that told you, 'This is the rules. This is what's gonna happen ... You either gonna do it or you're not. And if you don't, we're gonna go outside and have a ... leather strap negotiation." When asked what thing he would most like to change about the world, Ben responds, "The perception of tolerance ... the way it's defined ... [pause] I don't know how to explain that one."

Various interviewers explained that Ben was "very friendly but became very agitated, angry, even belligerent when discussing politics or social issues. At these points in the interview, he would point his fingers directly at me and get kind of a crazy look in his eye." Additionally, "He spoke unusually loudly in a fairly quiet environment," "loved to quote adages and proverbs," "went off topic very easily, rarely giving a direct answer," and "had an anxiety about being wrong, which he explained with a reference to being shown how wrong he was as a child."

In sum, Ben is an example of a well-mannered, self-described "normal old joe" who developed a RAGE disposition from his experiences of hardship, his sense that some Americans are "taking away" his values, and his frustration about his inability to stop it. For Ben, Christian nationalist ideology serves primarily as a tool to justify his deeper affective disposition, and "Christian values" serve as a proxy for the familiar customs he would like to see in society.

\section{"Flight for America"}

Three-quarters of Christian nationalist respondents conveyed experiences and emotions indicating that their FEAR system dominated their appraisals. This Christian nationalist type is characterized by anxiety, compliance, passivity, vacuous indifference, and internalization as a form of self-protection. Respondents claimed that their views were out of their control because "It's what the Bible says" and "God decided it, not me." Consistent with explanations of the FEAR system's goals (and not mere fear sentiments), these respondents avoided confrontation, were highly sensitive to potential threats, and displayed apprehensive worry and nervousness. 
Respondents of this type grew up in sheltered, homogeneous religious subcultures with harsh restrictions on behavior and activities and few encounters with diversity. They described authoritarian parents who made them feel shame and anxiety through frequent moral lecturing, manipulating their feelings, controlling their engagement with media and culture, and instilling fear through religious teachings about temptation, demons, and Hell. A 28-year-old man shared, "My dad was more of the disciplinarian, and he would try and fix my life, and he never actually took the time to understand what was wrong before he tried to fix it. He always thought he knew better than me. That stressed our relationship." A 25-year-old woman described feeling obligated to tell her dad about being raped. She said, "He flipped out! I don't think my dad has ever called me names like that before. He's thinking, 'My girl's gonna have all these diseases and have three kids out of wedlock and be in the streets!' Of course, I'm crying, I'm shaking ... the end result is my dad was absolutely mortified." Many women respondents also described experiences of gaslighting by boyfriends, frequently mentioning the idea of being made to feel "crazy."

The various interviewers noted similar themes in their field notes. They wrote, "Would duck her head and hold her shoulders in a way that indicated embarrassment or almost apology," "unsure how much she truly believes the majority of what she said ... she seemed to draw on ready-made answers," "sad, lonely, and barely holding it together ... had to fight back tears at multiple points," "severe self-doubt and insecurity. At times, seemed to almost get choked up, and then she'd close down," "processed [questions] out loud as if she was walking aimlessly and then would stumble across the worn path of religious verbiage that she could then follow," "very skittish and appears uncomfortable in her own skin," "was extremely self-conscious about not answering 'right' or 'sounding stupid.' Kept saying 'Oh, that is so sad that I can't answer that," and "would speak in whispers, alternate voices, and rarely made eye contact ... many times she slipped into a baby voice and would talk to the side." Some respondents were also aware of how traumatic experiences conditioned their FEAR. A 28-year-old woman shared, "I slowly died inside and became a shell of who I was ... I didn't have coping mechanisms ... For years I suppressed everything and internalized all the responses around me as my fault."

Eliza, a 17-year-old, upper-middle class Latter-day Saint girl from Utah, exemplified this type of Christian nationalism. Eliza lived with her two parents and siblings, was homeschooled until ninth grade, and said her friends were other homeschooled kids with the same values. She described her mom as her best friend multiple times, though she said they sometimes disagree about Eliza's weight. Eliza's parents make her drink two "nutrition shakes" daily, which she really dislikes. She nervously shares, "In the mornings ... like my Mom will want me to weigh myself and I won't, I don't know, I just, sometimes I, I say something else if I've gained a little bit of weight just to keep her calm or whatever." When asked about good and bad things in her life, Eliza responds, "Homeschool is a good ... and I think I'm so close with my family ... Some bad things, I'd say that people don't know who I am." She explained further that she does not go to many parties and gets depressed about her weight, adding, "If I mess it up one night and eat at a friend's house you know, and I gained instead of lost, that gets me really bad." 
When asked about religion, Eliza shared, "I was raised in an LDS family. Um, we are very religious ... We have very high standards. There is certain clothing that my Mom taught me when I was growing up that we just don't wear." Eliza also felt that the nation has lost its sense of right and wrong, claiming, "I definitely think we are becoming too accepting" and "I don't like all the skin they're showing in magazines ... the language ... all this lesbian crap and gay stuff."

In Wave 2, Eliza was married, but still lived with her parents. Her voice was soft, and she often sounded robotic when expressing her views. She shares, "I turned 19 on my wedding. [My parents] loved him ... It was a blind date. We were set up, and we ended up getting to know his family before he came home from his mission. They already said I was going to be part of the family, which is a little scary. I'm like "Okay." Eliza says she got married quickly because "Satan has more opportunity the more time he gets." When asked about her friends, Eliza responds, "My family ... I don't really want to be with others other than my family." She also claims, "I feel like the wonderful foundation that our founding fathers created in our nation is being lost. They say the times are changing, so the laws must change. I don't feel that way." She continues, "This thing about gay rights ... it's almost as if they ... and taking God out of the schools and trying to create it just as if He was never there, so the people that don't believe in Him would be happy ... it's so selfish to go as far to take it away from other people! Let's just live in peace."

By Wave 3, Eliza is dominated by worry. She worries about dangers outside at night, being misguided by the one-sided media, and Obama's campaign and its "going along with this whole global warming thing." She works part time for her dad, and says, "We're pretty close ... sometimes he will give me the man's perspective of things ... He says just how men, like for them, sex is reassuring them that they are loved. If they don't have that companionship more frequently, they feel ... like they're not the handsome hunk they always want to be for their wife." When asked about politics, she says, "It's just all doom and gloom ... that is why I hate hearing it because it gets me down ... I listen to Rush sometimes, and Glenn and Fox News. A little CNN, but that just seems so biased." She again brings up same-sex marriage: "I think they have the choice to try and struggle and not just give in ... I have some friends who are a lesbian and then a homosexual. I love them to death, but I don't love what they do. I don't want them to try and force upon me that I accept it." All of Eliza's political views are framed by FEAR.

Finally, in Wave 4, Eliza works part-time selling clothes and describes herself as a "homebody." When asked where she feels like she belongs, she says, "I'd say my family. Really like my immediate family ... I would say church members to a point." When asked to describe her religion, she claims, "We aren't laxing in our ... we aren't negotiated with [sigh] the world and what it's telling us morals are today." She adds, "Morals in general are being just relaxed, relaxed, relaxed, relaxed ... interacting with other people, it's almost like they want to force you to accept their lower standards in order to be their friend or something."

Eliza becomes highly emotional when shifting toward politics. She exclaims, "I think it's very important to maintain the freedoms that America was built upon, depends upon a moral people! [pause] And thus, I, uh-- a moral religious people!" She also says, "[exhales] It's like a tyranny of tolerance! They keep asking you to 
lower your standards, ya know, 'You wanna accept me? Then you need to lower your standards ... Like same-sex marriage ... [clears throat] It can ultimately affect my religion and how we choose to live!" Eliza claims to be conservative, which she says means "less meddling from the government ... Morals! Values! Standards!" Eliza grew up surrounded almost solely by her immediate family who controlled all her behaviors and invoked religious guilt and fear. Her experiences conditioned a dominating FEAR affect, leading her to perceive all undesirable changes and unfamiliar ways as a personal threat.

\section{Comparing Christian Nationalist Sociopolitical Concerns}

After identifying these two dominant affective types of Christian nationalism, I coded every sociopolitical issue mentioned in the interview section that asked about political concerns. Table $\mathrm{V}$ contains all issues and the frequency of respondents in each type who mentioned them.

The concerns of "Fighters" tied to safety, freedom, better economic prospects, and reducing government assistance, particularly to black Americans perceived as abusing the system. Their mentions of Obama, equal rights, and reverse racism also tied to their concerns about black Americans receiving unfair preferential treatment. These are characteristic of RAGE.

Many "Flighters" gave brief responses, insisting that they "don't do politics" when first asked about their views. However, once they opened up, they expressed an intense worry about the dangers of moral decline. The legalization of same-sex marriage and abortion were the top two political issues they mentioned. Though less salient than for "Fighters," the "Flight" type also expressed some concerns about economic issues and welfare, which they explained through the frame of moral decline, namely laziness. These views are characteristic of FEAR.

The first two rows of Table V show that over a quarter of "Fighters" mentioned that they "hate politics," and almost half of "Flighters" claimed they "avoid politics" when asked about their views. These responses also directly tie to their associated affective systems. Additionally, on the survey, 36\% of "Fighters" thought same-sex marriage was okay, compared to $0 \%$ of "Flighters." Sixty-three percent of "Flighters" said they cared very much about the poor, compared to only $18 \%$ of "Fighters." Sixty-three percent of "Flighters" also said they cared very much about racial equality, compared to only $27 \%$ of "Fighters." Though both types of Christian nationalists conveyed reactionary views, which they justified using Christian nationalist rhetoric, these findings show that their specific concerns differ. Understanding the RAGE and FEAR affective systems illuminates their specific motivations.

\section{DISCUSSION}

This article examines how Christian nationalist ideological views develop and the mechanisms by which they relate to sociopolitical attitudes. I conceptualize the fundamental role of affective systems in shaping ideological views and cultural 
TABLE V. Sociopolitical Issues of Concern as Expressed in Interviews

\begin{tabular}{lcc}
\hline & $\begin{array}{c}\text { Fight for America" } \\
N=11 \\
\text { \% of sample }\end{array}$ & $\begin{array}{c}\text { "Flight for America" } \\
N=30 \\
\% \text { of sample }\end{array}$ \\
\hline Avoids Politics & 9 & $\mathbf{4 3}$ \\
Hates Politics & $\mathbf{2 7}$ & 0 \\
Abortion & 9 & $\mathbf{4 3}$ \\
Big Government & $\mathbf{3 6}$ & 23 \\
Economy & 18 & 23 \\
Education & 0 & 3 \\
Equal Rights & 9 & 0 \\
Government Corruption & 0 & 17 \\
Gun Rights & $\mathbf{3 6}$ & 13 \\
Healthcare & $\mathbf{4 5}$ & 3 \\
Helping the Poor More & 0 & 7 \\
Immigration & 0 & 7 \\
Immorality & 9 & $\mathbf{7 0}$ \\
National Security & 0 & 3 \\
Obama & $\mathbf{4 5}$ & 13 \\
Political Correctness & 9 & 7 \\
Reverse Racism & 18 & 3 \\
Same-sex Marriage & 0 & 77 \\
Taxes & 9 & 3 \\
Violence & 9 & 3 \\
War & 9 & 23 \\
Welfare & $\mathbf{2 7}$ & 7 \\
\hline
\end{tabular}

Note: Issues mentioned by more than $25 \%$ of respondents are in bold.

attitudes - an enculturation process I call "affective conditioning." I then identify distinct traumatic upbringing experiences among respondents, which condition heightened RAGE and FEAR affective systems. While respondents' declarative beliefs appear incoherent and justificatory, respondents' attitudes strongly align with the motivational goals and expected behavior patterns of the RAGE and FEAR affective systems. These findings illuminate the crucial role of emotions in the enculturation process. They also offer new insights for understanding the dynamics of Christian nationalist views, as well as other reactionary political attitudes and the possibilities of change.

\section{The Roots of Christian Nationalism and Related Ideological Views}

Studies of Christian nationalism and related ideological views draw various boundaries around adherents. Some tend to focus on a demographic characterized as rural, forgotten, working-class American citizens (e.g., Hochschild 2016; Wuthnow 2018), while others focus on a suburban Religious Right demographic (e.g., Kruse 2015; Martí 2020). This study better specifies both the core and contours of group belonging by illuminating the underlying mechanisms that motivate these groups' ideological views. I show that one type of Christian nationalism is driven by RAGE, while the other is driven by FEAR. Respondents' unique experiences condition different affective dispositions and, consequently, different sociopolitical atti- 
tudes. These affective dispositions are non-reducible to tertiary sentiments of anger and fear.

Considering the arousal conditions and responses of the SEEKING, RAGE, and FEAR systems can similarly illuminate the dynamics of other theories of political ideology. For example, Altemeyer's (1981) widely used scale of right-wing authoritarianism involves elements of submission, aggression, and conventionalism. I describe specific affective mechanisms that foster submission, aggression, and conventionalism and illustrate why they are not best grouped together as a single personality trait. Similarly, themes in my findings connect to the "strict father" political orientation described in Lakoff's (2002) Moral Politics. However, while Lakoff's cognitive linguistic approach emphasizes the unconscious metaphorical mappings of parenting styles onto views about the government, my findings point to the biosocial mechanisms that give such unconscious cognitions their emotional valences.

Political psychologists have theorized similar connections between trauma, perceived threat, and political outcomes. Van Prooijen and Krouwel (2019) argue that extreme political ideologies on both the left and right are fueled by feelings of distress and result in black-and-white perceptions of the world and intolerance. Al-Kire et al. (2021) find that experimentally evoking a threat to Christianity increases Christian nationalist beliefs. Armaly et al. (2022:16) find that "[Christian nationalism's] effect on support for violence is essentially conditional" on white identity, perceived victimhood, and conspiratorial belief, and "attention to Christian nationalism should be contextualized rather than treated in isolation." My findings build on this work, explaining the specific mechanisms by which traumatic social experiences woven into everyday life can condition an enduring sense of threat over time. Future studies should examine how these affective systems work among other political ideologies and in other contexts.

\section{Reactionary Sociopolitical Attitudes and Possibilities for Change}

These findings also help explain the salience of reactionary sociopolitical attitudes in America's current political climate, which are expressed by, but not limited to, Christian nationalists. A limitation of this study is that it only focuses on those who verbalize Christian nationalist ideological views. Thus, the attitudes and underlying affective dispositions I identify likely apply to a larger subset of Americans, including at varying levels of intensity.

For Christian nationalists, threat sensitivity tied to changing ways and empowering out-groups strongly influences their reactionary sociopolitical attitudes. They sometimes use theological references to commandments, laws, and blessings. However, this religious rhetoric largely serves to justify deeper perceptions tied to the arousal of RAGE and FEAR systems.

Prior to "the rider and the elephant" metaphor, Haidt (2001) offered an equally if not more important metaphor, which the findings of this article support: "the emotional dog and its rational tail." A rationalist perspective "believe[s] that our own moral judgment (the dog) is driven by our own moral reasoning (the tail)" (Haidt 2001:823). By focusing on declarative beliefs and values, it assumes, "the successful rebuttal of an 
opponent's arguments [will] change the opponent's mind. Such a belief is like thinking that forcing a dog's tail to wag by moving it with your hand will make the dog happy" (Haidt 2001:823). Haidt (2001:825) continues, "It is easier to study verbal reasoning than it is to study emotions and intuitions, but reasoning may be the tail wagged by the dog. The dog itself may turn out to be moral intuitions and emotions."

So can RAGE- and FEAR-driven attitudes be changed? Though rational appeals are unlikely to have a lasting impact, Panksepp (1998) and Cozolino (2006) describe how exposure to unfamiliar and negatively perceived stimuli can recondition one's affective responses to them. Cozolino (2006:255) also describes the necessity of intention, attention, and time and describes strategies akin to cognitive behavioral therapy. Changing perceptions is difficult, but with effort and time, people can become aware of their affective responses and gradually change them. Trust is also important in this context. Otherwise, efforts to change perceptions are likely to be perceived as a form of "attack."

Another strategy implied by the findings of this study involves changing the culture in which people's affective systems are conditioned. This study identifies highly traumatic upbringings among respondents caused by authoritarian parenting practices, fear and guilt-based teachings, purity culture, and insulated subcultures promoted by particular strains of Christianity. Respondents' attitudes are strongly, lastingly, and negatively shaped by these experiences.

Finally, aspects of my findings parallel upbringing patterns described in studies of white supremacists. Simi et al. (2019) describe how former white supremacists' shift of their negative emotions toward their supremacist groups motivated them to disengage from those groups. Similarly, if the RAGE and FEAR of those with reactionary views were redirected toward different targets, such as the political leaders that fuel their RAGE and FEAR, their perceptions could significantly change and some of their attitudes might shift as well. These dynamics will be better understood as sociologists integrate affective conditioning into their studies.

\section{REFERENCES}

Abrutyn, Seth and Omar Lizardo. 2020. "Grief, Care, and Play: Theorizing the Affective Roots of the Social Self." Advances in Groups Processes 37: 79-108.

Aho, James A. 1995. The Politics of Righteousness: Idaho Christian Patriotism. Seattle: University of Washington Press.

Al-Kire, Rosemary L., Michael H. Pasek, Jo-Ann Tsang, and Wade C. Rowatt. 2021. "Christian No More: Christian Americans Are Threatened by their Impending Minority Status." Journal of Experimental Psychology 97: 1-10.

Altemeyer, Bob. 1981. Right-Wing Authoritarianism. Winnipeg: University of Manitoba Press.

Armaly, Miles T., David T. Buckley, and Adam M. Enders. 2022. "Christian Nationalism and Political Violence: Victimhood, Racial Identity, Conspiracy, and Support for the Capitol Attacks." Political Behavior 44: 937-960.

Asma, Stephen T. and Rami Gabriel. 2019. The Emotional Mind: The Affective Roots of Culture and Cognition. Cambridge, MA: Harvard University Press.

Baker, Joseph O., Samuel L. Perry, and Andrew L. Whitehead. 2020a. "Crusading for Moral Authority: Christian Nationalism and Opposition to Science.” Sociological Forum 35: 3: 587-607.

Baker, Joseph O., Samuel L. Perry, and Andrew L. Whitehead. 2020b. "Keep America Christian (and White): Christian Nationalism, Fear of Ethnoracial Outsiders, and Intention to Vote for Donald Trump in the 2020 Presidential Election." Sociology of Religion 81: 3: 272-293. 
Barkun, Michael. 1997. Religion and the Racist Right: The Origins of the Christian Identity Movement. Chapel Hill: The University of North Carolina Press.

Bloom, Paul. 2013. Just Babies: The Origins of Good and Evil. New York: Crown.

Boutyline, Andrei and Laura K. Soter. 2021. "Cultural Schemas: What they Are, how to Find Them, and What to Do Once You've Caught One." American Sociological Review 86: 4: 728-758.

Braunstein, Ruth. 2017. "Muslims as Outsiders, Enemies, and Others: The 2016 Presidential Election and the Politics of Religious Exclusion.” American Journal of Cultural Sociology 5: 3: 355-372.

Butler, Anthea. 2021. White Evangelical Racism: The Politics of Morality in America. Chapel Hill: The University of North Carolina Press.

Cerulo, Karen A., Vanina Leschziner, and Hana Shepherd. 2021. "Rethinking Culture and Cognition." Annual Review of Sociology 47: 63-85.

Collins, Randall. 2005. Interaction Ritual Chains. Princeton, NJ: Princeton University Press.

Cozolino, Louis. 2006. The Neuroscience of Human Relationships: Attachment and the Developing Social Brain. New York: W.W. Norton \& Company.

Damasio, Antonio. 1994. Descartes' Error: Emotion, Reasoning, and the Human Brain. New York: Penguin Books.

Danermark, Berth, Mats Ekström, Liselotte Jakobsen, and Jan Ch. Karlsson. 2002. Explaining Society. London: Routledge.

Davis, Joshua. 2018. "Enforcing Christian Nationalism: Examining the Link Between Group Identity and Punitive Attitudes in the United States." Journal for the Scientific Study of Religion 57: 2: 300-317.

Davis, Joshua T. and Samuel L. Perry. 2021. "White Christian Nationalism and Relative Political Tolerance for Racists." Social Problems 68: 3: 513-534.

Davis, Kenneth L. and Christian Montag. 2019. "Selected Principles of Panskeppian Affective Neuroscience." Frontiers in Neuroscience 12: 1025.

Edgell, Penny. 2017. “An Agenda for Research on American Religion in Light of the 2016 Election.” Sociology of Religion 78: 1: 1-8.

Edgell, Penny and Eric Tranby. 2007. "Religious Influences on Understandings of Racial Inequality in the United States." Social Problems 54: 2: 263-288.

Freud, Sigmund. 1961. Beyond the Pleasure Principle. New York: Norton.

Jeff, Goodwin, James M. Jasper, and Francesca Polletta. 2001. Passionate Politics: Emotions and Social Movements. Chicago: The University of Chicago Press.

Gorski, Philip. 2017. "Why Evangelicals Voted for Trump: A Critical Cultural Sociology." American Journal of Cultural Sociology 5: 3: 338-354.

Greene, Joshua D., R. Brian Sommerville, Leigh E. Nystrom, John M. Darley, and Jonathan D. Cohen. 2001. "An fMRI Investigation of Emotional Engagement in Moral Judgment." Science 293: 5537: 2105-2108.

Haidt, Jonathan. 2001. "The Emotional Dog and its Rational Tail: A Social Intuitionist Approach to Moral Judgment." Psychological Review 108: 4: 814-834.

Haidt, Jonathan. 2006. The Happiness Hypothesis. New York: Basic Books.

Hochschild, Arlie Russell. 1983. The Managed Heart: Commercialization of Human Feeling. Berkeley: University of California Press.

Hochschild, Arlie Russell. 2016. Strangers in their Own Land: Anger and Mourning on the American Right. New York: The New Press.

Hunzaker, M.B. Fallin and Lauren Valentino. 2019. "Mapping Cultural Schemas: From Theory to Method." American Sociological Review 84: 5: 950-981.

Ignatow, Gabe. 2021. "Cognitive Sociology after Relational Biology.” Sociological Forum 36: S1: 12531270.

Jasper, James M. 2018. The Emotions of Protest. Chicago: The University of Chicago Press.

Jones, Robert P. 2020. White Too Long: The Legacy of White Supremacy in American Christianity. New York: Simon \& Schuster.

Jost, John T., Jack Glaser, Arie W. Kruglanski, and Frank J. Sulloway. 2003. "Political Conservatism as Motivated Social Cognition." Psychological Bulletin 129: 3: 339-375.

Kemper, Theodore D. 1987. "How Many Emotions Are There? Wedding the Social and Autonomic Components." American Journal of Sociology 93: 2: 263-289.

Kiley, Kevin and Stephen Vaisey. 2020. "Measuring Stability and Change in Personal Culture Using Panel Data." American Sociological Review 85: 3: 477-506.

Kruse, Kevin M. 2015. One Nation under God: How Corporate America Invented Christian America. New York: Basic Books.

Lakoff, George. 2002. Moral Politics: How Liberals and Conservatives Think. Chicago: Chicago University Press. 
Leschziner, Vanina and Adam Isaiah Green. 2013. "Thinking about Food and Sex: Deliberate Cognition in the Routine Practices of a Field." Sociological Theory 31: 2: 116-144.

Leschziner, Vanina and Gordon Brett. 2021. "Have Schemas Been Good to Think with?" Sociological Forum 36: S1: 1207-1228.

Leys, Ruth. 2000. Trauma: A Genealogy. Chicago: University of Chicago Press.

Lizardo, Omar. 2017. "Improving Cultural Analysis: Considering Personal Culture in its Declarative and Nondeclarative Modes." American Sociological Review 82: 1: 88-115.

Lizardo, Omar. 2021. "Culture, Cognition, and Internalization.” Sociological Forum 36: S1: 1177-1206.

Lizardo, Omar, Robert Mowry, Brandon Sepulvado, Dustin S. Stoltz, Marshall A. Taylor, Justin Van Ness, and Michael Wood. 2016. "What Are Dual Process Models? Implications for Cultural Analysis in Sociology." Sociological Theory 34: 4: 287-310.

Martí, Gerardo. 2020. American Blindspot: Race, Class, Religion, and the Trump Presidency. Lanham: The Rowman \& Littlefield Publishing Group, Inc.

McDaniel, Eric Leon, Irfan Nooruddin, and Allyson Faith Shortle. 2011. "Divine Boundaries: How Religion Shapes Citizens' Attitudes toward Immigrants.” American Politics Research 39: 1: 205-233.

McVeigh, Rory and Kevin Estep. 2020. The Politics of Losing: Trump, the Klan, and the Mainstreaming of Resentment. New York: Columbia University Press.

Mills, C. Wright. 1940. "Situated Actions and Vocabularies of Motive." American Sociological Review 5: 6: 904-913.

Narvaez, Darcia. 2014. Neurobiology and the Development of Human Morality: Evolution, Culture, and Wisdom. New York: Norton.

Nelson, Eric E., Ellen Leibenluft, Erin B. McClure, and Daniel S. Pine. 2005. "The Social re-Orientation of Adolescence: A Neuroscience Perspective on the Process and its Relation to Psychopathology." Psychological Medicine 35: 2: 163-174.

Panksepp, Jaak. 1998. Affective Neuroscience: The Foundations of Human and Animal Emotions. New York: Oxford University Press.

Peirce, Charles. 1998 [1901]. "Sundry Logical Conceptions," In The Peirce Edition Project (ed.), The Essential Peirce: Selected Philosophical Writings, Volume 2: pp. 267-288. Bloomington: Indiana University Press.

Perry, Samuel L. and Andrew L. Whitehead. 2015. "Christian Nationalism and White Racial Boundaries: Examining Whites' Opposition to Interracial Marriage.” Ethnic and Racial Studies 38: 10: 1671-1689.

Perry, Samuel L. and Andrew L. Whitehead. 2019. "Christian America in Black and White: Racial Identity, Religious-National Group Boundaries, and Explanations for Racial Inequality." Sociology of Religion 80: 3: 277-298.

Perry, Samuel L., Andrew L. Whitehead, and Joshua B. Grubbs. 2020. "Culture Wars and COVID-19 Conduct: Christian Nationalism, Religiosity, and Americans' Behaviors during the Coronavirus Pandemic." Journal for the Scientific Study of Religion 59: 3: 405-416.

Perry, Samuel L., Andrew L. Whitehead, and Joshua T. Davis. 2019. "God's Country in Black and Blue: How Christian Nationalism Shapes Americans' Views About Police (Mis)Treatment of Blacks." Sociology of Race and Ethnicity 5: 1: 130-146.

Plutchik, Robert. 1980. “A General Psychoevolutionary Theory of Emotion,” In Robert Plutchik and Henry Kellerman (eds.), Emotion: Theory, Research, and Experience, Volume 1: pp. 3-33. New York: Academic Press.

Pugh, Allison J. 2013. "What Good Are Interviews for Thinking about Culture? Demystifying Interpretive Analysis." American Journal of Cultural Sociology 1: 1: 42-68.

Rotolo, Michael. 2020. "Religion Imagined: The Conceptual Substructures of American Religious Understandings.” Sociological Forum 35: 1: 167-188.

Rotolo, Michael. 2021. "Culture Beneath Discourse: A Conceptual Model for Analyzing Nondeclarative Cultural Knowledge." American Journal of Cultural Sociology.

Simi, Pete, Karyn Sporer, and Bryan F. Bubolz. 2016. "Narratives of Childhood Adversity and Adolescent Misconduct as Precursors to Violent Extremism: A Life-Course Criminological Approach." Journal of Research in Crime and Delinquency 53: 4: 536-563.

Simi, Peter, Steven Windisch, Daniel Harris, and Gina Ligon. 2019. "Anger from Within: The Role of Emotions in Disengagement from Violence Extremism." Journal of Qualitative Criminal Justice \& Criminology $7:$ : 2: 3-28.

Smith, Christian and Melinda Lundquist Denton. 2005. Soul Searching: The Religious and Spiritual Lives of American Teenagers. New York: Oxford University Press.

Summers-Effler, Erika. 2010. Laughing Saints and Righteous Heroes: Emotional Rhythms in Social Movement Groups. Chicago: The University of Chicago Press. 
Summers-Effler, Erika, Justin Van Ness, and Christopher Hausmann. 2015. "Peeking in the Black Box: Studying, Theorizing, and Representing the Micro-Foundations of Day-to-Day Interactions." Journal of Contemporary Ethnography 44: 4: 450-479.

Swidler, Ann. 1986. "Culture in Action: Symbols and Strategies." American Sociological Review 51: 2: 273-286.

Timmermans, Stefan and Iddo Tavory. 2012. "Theory Construction in Qualitative Research: From Grounded Theory to Abductive Analysis." Sociological Theory 30: 3: 167-186.

Tomkins, Silvan S. 1965. "Affect and the Psychology of Knowledge," In Silvan S. Tomkins and Carroll E. Izard (eds.), Affect, Cognition, and Personality: pp. 72-97. New York: Springer.

Turner, Jonathan H. 2007. Human Emotions: A Sociological Theory. New York: Routledge.

Turner, Jonathan H. and Jan E. Stets. 2006. "Sociological Theories of Human Emotions." Annual Review of Sociology 32: 25-52.

Vaisey, Stephen. 2009. "Motivation and Justification: Toward a Dual-Process Theory of Culture in Action." American Journal of Sociology 114: 6: 1675-1715.

Jan-Willem, Van Prooijen and André P.M. Krouwel. 2019. "Psychological Features of Extreme Political Ideologies." Current Directions in Psychological Science 28: 2: 159-163.

Whitehead, Andrew L. and Samuel L. Perry. 2015. "A More Perfect Union? Christian Nationalism and Support for Same-Sex Unions.” Sociological Perspectives 58: 3: 422-440.

Whitehead, Andrew L. and Samuel L. Perry. 2020. Taking America Back for God: Christian Nationalism in the United States. New York: Oxford University Press.

Whitehead, Andrew L., Samuel L. Perry, and Joseph O. Baker. 2018a. "Make America Christian Again: Christian Nationalism and Voting for Donald Trump in the 2016 Presidential Election." Sociology of Religion 79: 2: 147-171.

Whitehead, Andrew L., Landon Schnabel, and Samuel L. Perry. 2018b. "Gun Control in the Crosshairs: Christian Nationalism and Opposition to Stricter Gun Laws." Socius 4: 1-13.

Winchester, Daniel. 2016. "A Hunger for God: Embodied Metaphor as CulturalCognition in Action." Social Forces 95: 2: 585-606.

Wood, Michael Lee, Dustin S. Stoltz, Justin Van Ness, and Marshall Taylor. 2018. "Schemas and Frames." Sociological Theory 36: 3: 244-261.

Wuthnow, Robert. 2018. The Left behind: Decline and Rage in Rural America. Princeton, NJ: Princeton University Press. 